Volume 3

5-9-2019

The Intricacies of Capturing the Holdings of a Mosque Library in Yemen: The Library of the Shrine of Imām al-Hādì, Șa $\varsigma_{\mathrm{da}}$

Sabine Schmidtke

Institute for Advanced Study, scs@ias.edu 


\title{
The Intricacies of Capturing the Holdings of a Mosque Library in Yemen: The Library of the Shrine of Imām al-Hādī, Șa ${ }^{\circ}$ da
}

\begin{abstract}
This article discusses the "The Zaydi Manuscript Tradition (ZMT)" initiative. The initiative aims to salvage the Zaydi literary tradition by gathering digital surrogates of as many Zaydi manuscripts as possible in a single repository and providing comprehensive and systematic open access to them for scholars worldwide, regardless of whether the physical manuscripts are preserved in Europe or in North America, in Yemen or elsewhere in the Middle East. The ZMT is a joint project initiated by the Institute for Advanced Study (IAS), Princeton, in partnership with the Hill Museum \& Manuscript Library (HMML) at Saint John's University, Collegeville, Minnesota. Work on the ZMT began in September 2016 and to date the project comprises some 1,000 digitized manuscripts from several European and Yemeni libraries which are accessible online through the project's Portal and HMML's virtual reading room.
\end{abstract}

\section{Keywords}

Yemen, Zaydism, endangered archives, cultural heritage preservation, manuscript studies 


\section{MANUSCRIPT STUDIES}

A Journal of the Schoenberg Institute for Manuscript Studies

VOLUME 3, NUMBER 1

(Spring 2018)

Manuscript Studies (ISSN 2381-5329) is published semiannually

by the University of Pennsylvania Press

The Schoenberg Institute
for Manuscript Studies
University of Pennsyivania Libraries 


\title{
MANUSCRIPT STUDIES
}

A Journal of the Schoenberg Institute for Manuscript Studies

VOLUME 3, N UMBER 1

\author{
Special Issue: \\ The Syriac Galen Palimpsest \\ Editors: William Noel and Ralph M. Rosen
}

\section{Articles}

The Syriac Galen Palimpsest Project: An Introduction

William Noel and Ralph M. Rosen

Pulling It All Together: Managing the Syriac Galen

Palimpsest Project

Michael B. Тотн

The Codicology and Conservation of the Syriac

Galen Palimpsest

Abigail B. Quandt and Renée C. WolcotT

Spectral Imaging Methods Applied to the Syriac

Galen Palimpsest

Roger L. Easton, Jr., Keith T. Knox, William A. Christens-Barry, AND Ken Boydston

The Galen Palimpsest and the Modest Ambitions of the

Digital Data Set

Doug EMERY

The Syriac Galen Palimpsest: A Tale of Two Texts

Naima Afif, Siam Bhayro, Grigory Kessel, Peter E. Pormann,

William I. Sellers, and Natalia Smelova 
iv | Journal for Manuscript Studies

Analyzing Images, Editing Texts: The Manchester Project

Naima Afif, Siam Bhayro, Peter E. Pormann, William I. Sellers,

and Natalia Smelova

The Textual Interest of the Syriac Versions of Galen's Simples

Irene Calà, Jimmy Daccache, and Robert Hawley 186

\section{Annotations}

Of Scribes and Scripts: Citizen Science and the Cairo Geniza

Preserving Endangered Archives in Jerba, Tunisia:

The al-Bāsī Family Library Pilot Project

Ali Boujdidi And Paul M. Love

The Intricacies of Capturing the Holdings of a Mosque

Library in Yemen: The Library of the Shrine of Imām alHādī, Șa da

Sabine Schmidtke

Compilation, Collation and Correction in the Time of Encyclopedism: The Case of UPenn LJS 55

Nathalie Lacarrière

Mapping Manuscript Migrations: Digging into Data for the History and Provenance of Medieval and Renaissance

Manuscripts

Toby Burrows, Eero Hyvönen, Lynn Ransom, and Hanno Wijsman

\section{Reviews}

Ahmad 'Abd al-Bāsiṭ. Catalogue of the Private Collections of

Manuscripts in the Egyptian National Library

ELIAS G. SABA 
David T. Gura. A Descriptive Catalogue of the Medieval and Renaissance Manuscripts of the University of Notre Dame and Saint Mary's College

Lisa Fagin Davis

Christopher De Hamel. Meetings with

Remarkable Manuscripts

Daniel Traister 
Schmidtke: The Intricacies of Capturing the Holdings of a Mosque Library in 


\title{
The Intricacies of Capturing the Holdings of a Mosque Library in Yemen
} The Library of the Shrine of Imām al-Hādì, Șa'da

\author{
SABINe SCHMIDTKE \\ Institute for Advanced Study
}

\section{Heritage Under Threat}

He libraries of Yemen are well known to be treasure troves not only for the rich and still largely unexplored literary tradition of the Zaydi branch of Shiism but also for a much wider spectrum of Islamic intellectual history, beyond Zaydism. The history of Zaydism in Yemen dates back to the ninth century CE when Imām al-Hādī Yahyā b. al-Husayn (d. 298/911) founded a Zaydi state with Șa da as his capital. When in the sixth/twelfth century the Zaydis of Yemen became politically unified with their coreligionists in the Caspian region of northern Iran, where a second Zaydi state had been established during the ninth century, a transfer of scholars and books set in from northern Iran, a leading intellectual center at the time, to Yemen.

Some of the libraries in Yemen that were founded during this period still exist today. This is the case, by way of example, for the library that was

\footnotetext{
I wish to thank Camilla Adang and Hassan Ansari for their comments on an earlier draft of this contribution, and Gabriele vom Bruck for confirmation that the library of al-Imām al-Hādī is still intact, while the samsarat al-Hādī has been destroyed (personal communication, 9 September 2017), most likely as a result of the bombarding of Șa da on 9 May 2015.
} 
founded by Imām al-Manșūr bi-llāh 'Abd Allāh b. Hamza (r. 593/1197614/1217) in his capital Zafär. The library grew steadily over the centuries and was transferred during the early twentieth century to the newly founded al-Khizāna al-mutawakkiliyya, nowadays the Maktabat al-Awqāf or alMaktaba al-Sharqiyya, located on the premises of the Great Mosque in Sanaa in an annex building that had been constructed for this purpose by order of Imām Yahyā b. Muhammad Hamīd al-Dīn (r. 1904-48). ${ }^{1}$

On the other hand, many of the libraries of Yemen were time and again affected by instances of loss of books through theft, confiscations, and even destruction of entire collections. In the course of Imām al-Manșūr's all-out war against the Mutarrifiyya sect during the thirteenth century, for example, nearly the entire literary legacy of the Muțarrifîs was destroyed. Incidents of destruction of private book collections also occurred during the Ottoman occupation of major parts of Yemen, between 1547 and 1629 and again between 1872 and 1918. ${ }^{2}$ Moreover, from the second half of the nineteenth century onwards, manuscripts became a highly valuable commodity when European, Ottoman-Turkish, and Saudi merchants and travelers to Yemen began to purchase thousands of manuscripts that are nowadays housed by libraries outside of the country. In fact, one of the principal purposes behind Imam Yahyā Hamīd al-Dīn's previously mentioned founding in 1925 of the Khizāna al-mutawakkiliyya in Sanaa, where he had the remains of the former ruler's library in Zafār transferred, together with the holdings of many other historical libraries, was to put a stop to theft and other losses. The

1 Cf. R. B. Serjeant and Ronald Lewcock, eds., Șan ' $\bar{a}$ ': An Arabian Islamic City (London: The World of Islam Festival Trust, 1983), 350b; Ismā'īl b. 'Alī al-Akwa', "al-Turāth al-fikrī fî̀ ghābir al-Yaman wa-ḥạ̄irihā,” Majallat Majma' al-lugha al-'arabiyya al-urdun̄ 4 xi-xii (1401/1981): 83-86; Brinkley Messick, The Calligraphic State: Textual Domination and History in a Muslim Society (Berkeley: University of California Press, 1996), 119-22; Horst Kopp and Eugen Wirth, Beiträge zur Stadtgeographie von Sana'a, Beihefte zum Tübinger Atlas des Vorderen Orients, Reihe B, Geisteswissenschaften 95 (Wiesbaden: Reichert, 1990), 38.

2 See, e.g., Serjeant and Lewcock, Șan' $(\bar{a}), 90 \mathrm{~b}$, which relates that the governor of Sanaa, Aḥmad b. Aḥmad al-Haymī al-Suwaydī, out of revenge, had the house of the scholar Sayyid Aḥmad al-Kibsī plundered and destroyed, including the latter's large library. The person in question is most likely Aḥmad b. Muhamamad b. Muhammad b. 'Abd Allāh b. 'Alī al-Kibsī (1239/1823-24-1316/1898-99); on him, see 'Abd al-Salām b. 'Abbās al-Wajīh, Aqām almu'allifīn al-Zaydiyya (McLean, VA: Mu'assasat al-Imām Zayd b. 'Alī al-thaqāfiyya, 1420/ 1999), 186-87n174. 
numerous codices that had originally been produced for the library of Imām al-Manșūr bi-llāh and were sold at the end of the nineteenth and beginning of the twentieth centuries to various libraries in the Middle East and Europe indicate that this was indeed a serious concern. Confiscations of private libraries also frequently occurred over the course of the twentieth century. In 1948, when Imām Aḥmad b. Yahyā Hamīd al-Dīn (r. 1948-62) ordered the execution of 'Alī b. Muhammad al-Wazìr, who served at the time as president of the parliament, and had some of the houses of the Bayt al-Wazir demolished, the library of the Bayt al-Wazir was confiscated and taken to the Great Mosque in Sanaa. ${ }^{3}$ Following the coup d'état of 1962, the former palace library and the personal collections of the members of the royal family, as well as the collections of former ministers and other government officials, were confiscated and eventually transferred to the Maktaba al-garbiyya and later on to the newly founded Dār al-makhțūtāat.

Over the second half of the twentieth and the first decades of the twentyfirst century, Yemeni authorities have been constantly fighting manuscript dealers, trying to prevent them from smuggling manuscripts out of the country. ${ }^{4}$ Moreover, many of the libraries of Yemen have been severely damaged, looted, or even destroyed over the past few decades as a result of the political turmoil and wars that Yemen has witnessed, and the continuing war in the country, with daily bombardments, constitutes an imminent threat not only to the local population but also to the cultural heritage of the country, including its many libraries. ${ }^{5}$

3 Cf. Gabriele vom Bruck, Islam, Memory, and Morality in Yemen: Ruling Families in Transition (Basingstoke: Palgrave Macmillan, 2005), 79-80. Cf. also Kopp and Wirth, Beiträge zur Stadtgeographie von Sana'a, 41.

4 See, e.g., "Antiquities \& Manuscripts Captured with Three Persons," 2008, http://www. almotamar.net/en/4739.htm; “Attempted Smuggle of 40 Manuscripts, Failed,” 2008, http:// www.almotamar.net/en/5414.htm; "51 Yemeni Antiquity Pieces, 312 Manuscripts Seized," 2010, http://www.almotamar.net/en/7886.htm; Fakhri Al-Arashi, "14 Stolen Manuscripts Returned to the Ministry of Culture," National Yemen, 2013, https://nationalyemen.com/ 2013/11/17/14-stolen-manuscripts-returned-to-the-ministry-of-culture/; Nasser Al-Sakkaf, “Authorities Thwart Smuggling of 14 Historic Manuscripts,” 2013, https://www.yementimes. com/en/1731/news/3152/Authorities-thwart-smuggling-of-14-historic-manuscripts.htm.

5 For details, see David Hollenberg and Anne Regourd, "Manuscript Destruction and Looting in Yemen: A Status Report," Chroniques du manuscrit au Yémen 21 (2016): 157-77; Lamya Khalidi, "The Destruction of Yemen and Its Cultural Heritage," International Journal 


\section{Salvaging the Zaydī/Yemeni Manuscript Tradition, 1951-2017}

In view of the richness and the uniqueness of the manuscript holdings of the many public and private libraries in Yemen, various international projects have been launched since the early 1950s to salvage some of these treasures. In 1951-52, in 1964, and again in 1974, scholarly expeditions from Egypt were dispatched to Yemen. They explored the holdings of the various public libraries in Sanaa as well as those of some of the smaller libraries in Sanaa and other cities, and produced microfilms of selected manuscripts, which they brought back to Cairo. In 1982, a delegation from Kuwait assessed and partly microfilmed the manuscripts of the Maktabat al-aḥqāf in Tarīm in Hadhramaut, and in 1985 a Kuwaiti team engaged in filming and cataloging some 308 manuscripts held by the Dār al-makhțuțāt in Sanaa. Iranian governmental and private institutions also engaged in filming significant numbers of Yemeni manuscripts at the turn of the millennium.

The various initiatives to produce surrogates of manuscripts, be it in microform or digitally, did not aim at preserving the manuscripts - the intention was rather to make them accessible to the respective local scholarly community in Egypt, Kuwait, or Iran, hence the selective approach in all those endeavors. Characteristically, the surrogates are housed in the relevant institution that was in charge of filming them in the first place, with no attempt to make them available to a larger audience. It is only in the case of Iran that the digital surrogates prepared were also made available to the Mu'assasat alImām Zayd b. 'Alī al-thaqāfiyya (Imam Zayd bin Ali Cultural Foundation = IZbACF) in Sanaa, whose personnel continued to digitize the holdings of additional private libraries. The various recent digitization efforts supported

\footnotetext{
of Middle East Studies 49 (2017): 735-38; "Damages on Yemeni Culture Sector and Heritage by Saudi-US Aggression in 1000 Days,” 2017, https://www.yemenpress.org/slider/damages -on-yemeni-culture-sector-and-heritage-by-saudi-us-aggression-in-1000-days.html. See also generally "Decision 40 COM 7 State of Conservation of World Heritage Properties," World Heritage Committee, 2016, and "Security Council Condemns Destruction, Smuggling of Cultural Heritage by Terrorist Groups," March 2017. Generally on the history of the Zaydi/ Yemeni manuscript tradition, see Sabine Schmidtke, "Preserving, Studying, and Democratizing Access to the World Heritage of Islamic Manuscripts: The Zaydī Tradition,” Chroniques du manuscrit au Yémen 23, n.s. 4 (2017): 103-66.
} 
by the German Foreign Office ${ }^{6}$ and the Deutsche Forschungsgemeinschaft in conjunction with the National Endowment for the Humanities ${ }^{7}$ also aimed at capturing a select number of private collections. The holdings of seven personal libraries in Sanaa and Kawkabān were digitized in the course of the two projects, some three hundred manuscripts in total. Again, only a fraction of these digitized materials are available through open access to date.

The Zaydi Manuscript Tradition (ZMT) aims at salvaging the Zaydi literary tradition by gathering digital surrogates of as many Zaydi manuscripts as possible in a single repository and providing comprehensive and systematic open access to them for scholars worldwide, regardless of whether the physical manuscripts are preserved in Europe or in North America, in Yemen, or elsewhere in the Middle East. The ZMT is a joint project initiated by the Institute for Advanced Study (IAS), Princeton, in partnership with the Hill Museum and Manuscript Library (HMML) at Saint John's University, Collegeville, Minnesota. Work on the ZMT began in September 2016, and to date the project comprises some 1,500 digitized manuscripts from several European and Yemeni libraries, which are accessible online through the project's portal and HMML's virtual reading room. The initiative consists of two components: (1) a digital portal on the IAS website that serves as a comprehensive research guide to relevant collections of Zaydi manuscripts, providing precise information on the location of each collection with a full list of its holdings and the relevant bibliography for every single codex. ${ }^{8}$ The digital portal further functions as a gateway to (2) the manuscript surrogates that are available in HMML's virtual reading room ( $v$ HMML), ${ }^{9}$ which serves as a repository of digital surrogates of manuscript

6 "Preserving Yemen's Cultural Heritage: The Yemen Manuscript Digitization Project," 2010. See Sabine Schmidtke and Jan Thiele, Preserving Yemen's Cultural Heritage: The Yemen Manuscript Digitization Project, Hefte zur Kulturgeschichte des Jemen 5 (Sanaa: Botschaft der Bundesrepublik Deutschland \& Deutsches Archaeologisches Institut, Orient-Abteilung, Außenstelle Sanaa, 2011).

7 “The Yemen Manuscript Digitization Initiative,” 2010-13. See https://ymdi.uoregon.edu/ and http://pudl.princeton.edu/collections/pudl0079, accessed 5 October 2017.

8 www.ias.edu/digital-scholarship/zaydi_manuscript_tradition, accessed 5 October 2017.

9 www.vHMML.org, accessed 5 October 2017. 
codices and will eventually include full metadata for the manuscripts through its cataloging tools.

\section{The Library of the Shrine of Imām al-Hādì, Șa'da}

Among the collections that have recently been processed for inclusion in the ZMT project are the manuscripts of the library of the Imām al-Hādi mosque in Șa da. ${ }^{10}$ The history and current situation of the collection is characteristic for many manuscript libraries of Yemen, private as well as public. While the mosque was constructed during the lifetime of the Imam al-Hādī in the ninth century, the library was not set up until the early twentieth century, together with the madrasa 'ilmiyya, which is also located on the premises of the mosque. ${ }^{11}$ While the library was counted at some point among the most important mosque libraries of Yemen, the situation began to deteriorate sometime before the revolution of 1962 with the appointment of al-qā dì Hasan [b.] Șalāh Dabbāsh as its custodian, who was succeeded after his demise by his son, Șālih. During their terms the library suffered from neglect and was subject to regular incidents of burglary and theft. The situation improved again during the 1990s following the appointment of Aḥmad b. Muhammad b. 'Alī al-Shāmī (1926-2013) as minister of religious endowments and guidance (wazìr al-awqāf wa-l-irshād). ${ }^{12} \mathrm{Al}-\mathrm{Shām} \overline{1}$ took measures to salvage the library and encouraged the preparation of a catalog of its holdings.

10 ZMT 01600 through 01675. See the entire collection at https://www.vhmml.org/reading Room/, accessed 5 October 2017. Search "ZMT" in the HMML Project Number field.

11 The following brief account of the history of the library is based on 'Abd Allāh Hammūd Dirham al-'Izzī, Fibris makbțūtāt maktabat mazār al-Imām Yabyā b. al-Husayn al-Hād̄̄ ilā l-ḅaqq. Șa'da, al-Jumbūriyya al-yamaniyya (Qum/Tehran: Kitābkhāna-yi buzurg-i hạạrat Āyat Allāh al-'uẓmā Mar'ashī Najafī/Wizārat-i umūr-i khārijiyya, 1425/2004), 1-12. For the Imām al-Hādī mosque, see also Else Niewöhner-Eberhard, Șa'da: Bauten und Bewobner in einer traditionellen islamischen Stadt, Beihefte zum Tübinger Atlas des Vorderen Orients, Reihe B, Geisteswissenschaften 64 (Wiesbaden: Reichert, 1985), 234-35. See also figure 1. 12 On him, see al-Wajīh, A Aàm al-mu'allifìn al-Zaydiyya, 179-80n168, http://www.yemeress. com/alkhabar/57129, accessed 5 October 2017. 


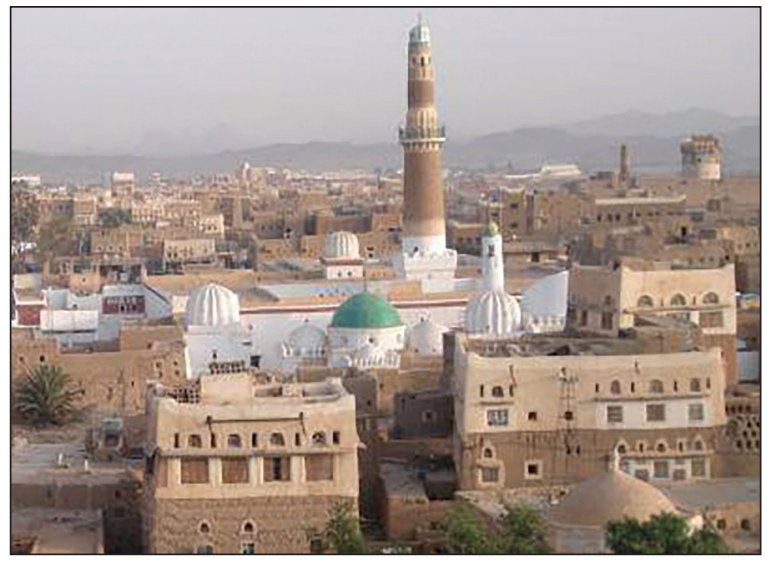

FIGURE 1. Photograph of the Imām al-Hādì mosque complex, dated 20 March 2015 (i.e., prior to the bombardment of 9 May 2015). Source: http://mandabpress.com/news6959. html.

In his survey of manuscript libraries of Yemen of 1993, 'Abd al-Wahhāb 'Alī al-Mu'ayyad (d. 2005) gives the total number of manuscripts in the collection as "ca. 100," adding that "the collection has been halved over the last thirty years owing to several factors, including war." ${ }^{13}$ The figure provided by al-Mu'ayyad is corroborated by a catalog prepared by 'Abd Allāh Hammūd Dirham al-'Izzī. The highest shelfmark recorded by al-'Izzī is "218," while his catalog covers a total of only 131 codices. Assuming that the collection has again grown since 1993, this would confirm al-Mu'ayyad's statement that the collection had been halved over the past three decades. Al-'Izzī had completed his descriptions of the collection in May $2000^{14}$ — the Iranian scholar Sayyid 'Alī Mūjānī relates in his preface to al-'Izzī's catalog that when he visited Șa'da in 2002, he was approached by al-'Izzī, who inquired about possibilities to have the catalog published. As a result of his

13 'Abd al-Wahhāb 'Ali al-Mu'ayyad, "Yemen," in Geoffrey Roper, ed., World Survey of Islamic Manuscripts (London: Al-Furqan Islamic Heritage Foundation, 1994), 3:661.

14 He signs the introduction (muqaddama) with the dates 2 Șafar 1421/6 May 2000 (Fibris, p. jim). 
mediation, Maḥmūd Maráashī, the head of the Āyat Allāh Marashī Najafī Library in Qum, accepted al-Izzîs Fibris for publication, which was realized, as previously mentioned, in 2004. In return, the Iranians were granted the right to produce digital surrogates of a select number of codices that are nowadays accessible in various libraries in Iran, including the Marashī library in Qum. Al-'Izzī's Fibris is included verbatim and in its entirety by 'Abd al-Salām al-Wajīh in his Mașādir al-turāth fì l-maktabāt al-khāșșa fī l-Yaman, ${ }^{15}$ though the latter fails to credit al-'Izzī for his work. Al-'Izzī is only mentioned insofar as al-Wajīh includes al-Izzîs introduction (pp. 429-32), with the latter's signature at its end (p. 432).

Al-'Izzī arranged his descriptions of the manuscripts in his Fibris according to the following disciplines: Qurānic sciences and exegesis (pp. 13-16), traditions (pp. 17-19), theology (pp. 21-27), legal theory (pp. 29-33), law (pp. 35-67), law of inheritance (pp. 69-71), grammar (pp. 73-85), rhetorics (pp. 87-89), ascetism and mysticism (pp. 91-93), and multitext volumes (pp. 95-133). This structure disagrees with the arrangement of the manuscripts in the library itself, as is indicated by the shelfmarks recorded by al-Izzī. The original library arrangment looks as presented in table 1.

The digital surrogates of manuscripts from the library that were produced at the time amount to seventy codices in total. In table 2 , those listed in al-Izzîs catalog that have been digitized are marked in bold.

In addition to these, the digital collection of the Imām al-Hādī library comprises twenty-one codices that are not described in al-'Izzìs catalog. The possibility that these constitute later additions to the library cannot be ruled out, though it might be more plausible that al-'Izzî's catalog covers only a part of the library's holdings. The actual size and scope of its manuscript collection thus remains uncertain-an observation that applies to most if not all published catalogs of private manuscript collections in Yemen.

Al-Izzì's partial catalog of the collection and, more importantly, the digital surrogates that are now accessible through $v$ HMML provide a sound material basis to study the curriculum that was taught at the madrasa 'ilmiyya

15 'Abd al-Salām b. 'Abbās al-Wajīh, Maṣādir al-turāth fī l-maktabāt al-kbāsṣa fī l-Yaman (McLean, VA: Mu'assasat al-imām Zayd b. 'Alī al-thaqāfiyya, 2002), 2:429-514. 
TABLE 1. Arrangement of the Manuscripts in the Library.

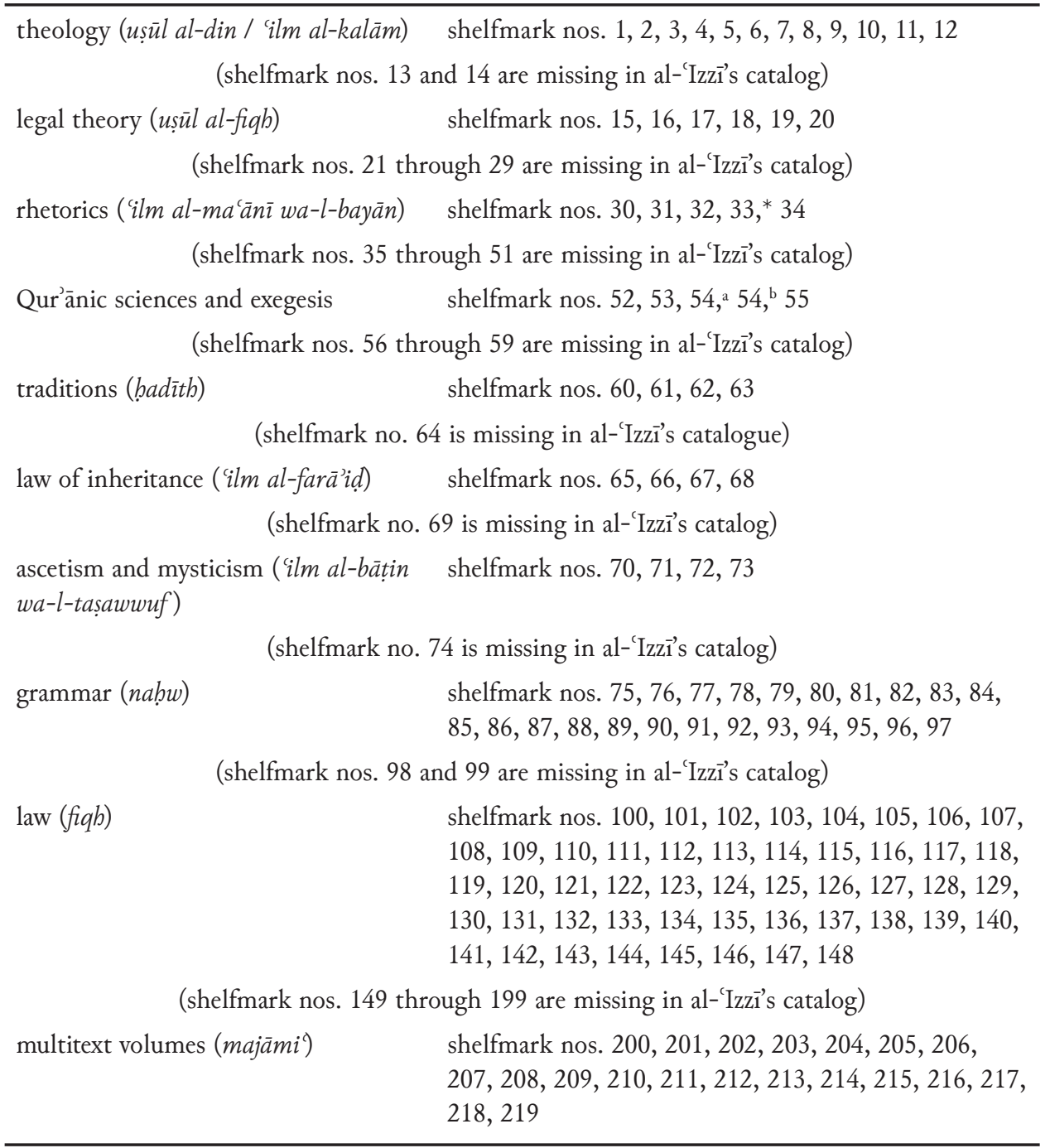

* Al-'Izzī lists two works in his catalogue as bearing the shelfmark "33," Kitāb 'Arūs al-afrāb sbarḅ Talkhīs al-Miftāḥ, by Bahāò al-Dīn Aḥmad b. 'Ali b. 'Abd al-Kāfī al-Subkī (d. 772 AH/1370-71 CE) (p. 88-al-'Tzzī erroneously attributes the work to al-Taftāzānī) and Kitāb al-Rawḍ al-ḅăfil al-jāmi' limā shi'ta min ma ān̄ al-Käfll, by Ibrāhīm b. Muhammad b. Ahmad b. 'Izz al-Dīn (p. 33). In view of the context, it is more likely that shelfmark no. 33 refers to al-Subki’s work: Nos. 30 through 34 consist of two copies of Muhammad b. 'Abd al-Raḥmān al-Qazwīnīs (d. 739/1338) Talkbīṣ al-miftāḥ, with several commentaries and supercommentaries on the work, viz. al-Muṭawwal by Sa'd al-Dīn al-Taftāzānī, al-Subkì’s 'Arūs al-afrāḅ sharḅ Talkbīs al-Miftāạ, and glosses by al-Fāḍil Hasan al-Shiblī on the Muțawwal. For al-Qazwīnīs Talkhịs al-Miftāṭ and the later commentary literature on the work, see Carl Brockelmann, Gescbichte der arabischen Litteratur (GAL). Erweitert um ein Vorwort von Jan Just Witkam (Leiden: Brill, 2012), 1:353f, vol. S 1:516-18. 
TABLE 2. Digital Surrogates of Manuscripts from the Library.

\begin{tabular}{|c|c|}
\hline theology (ușūl al-din / 'ilm al-kalām) & nos. $\underline{\mathbf{1}}, 2,3,4, \underline{\mathbf{5}}, \underline{\mathbf{6}}, \underline{\mathbf{7}}, \underline{\mathbf{8}}, \underline{\mathbf{9}}, 10,11, \underline{\mathbf{1 2}}$ \\
\hline legal theory (ușūl al-fiqb) & nos. $\underline{\mathbf{1 5}}, 16,17, \underline{\mathbf{1 8}}, 19, \underline{\mathbf{2 0}}$ \\
\hline rhetorics ('ilm al-ma'ānī wa-l-bayān) & nos. $30,31, \underline{32}, 33,34$ \\
\hline Qur'ānic sciences and exegesis & nos. $52, \underline{53}, \underline{54^{\mathrm{a}}}, \underline{54^{\mathrm{b}}}, \underline{55}$ \\
\hline traditions (badìth) & nos. $60,61,62,63$ \\
\hline law of inheritance ('ilm al-farā’id) & nos. $\underline{65}, \underline{66}, \underline{67}, \underline{68}$ \\
\hline ascetism and mysticism & nos. $\underline{70}, \underline{71}, \underline{72}, \underline{73}$ \\
\hline $\operatorname{grammar}(n a b ̧ w)$ & $\begin{array}{l}\text { nos. } \mathbf{7 5}, \underline{76}, \underline{77}, 78,79, \underline{80}, 81,82,83, \underline{84}, 85,86, \\
\underline{87}, 88, \underline{\mathbf{8 9}}, \mathbf{9 0}, \mathbf{9 1}, \underline{\mathbf{9 2}}, \mathbf{9 3}, \mathbf{9 4}, 95,96,97\end{array}$ \\
\hline law $(f i q b)$ & $\begin{array}{l}\text { nos. } 100,101,102,103,104,105, \underline{106}, \underline{107}, 108, \\
109,110,111,112,113,114, \underline{115}, 116,117,118, \underline{119}, \\
\underline{\mathbf{1 2 0}}, 121, \underline{122}, 123, \underline{\mathbf{1 2 4}}, 125,126,127,128,129, \\
130,131,132,133,134,135,136,137,138,139, \\
140,141,142,143,144,145, \underline{146}, 147,148\end{array}$ \\
\hline multitext volumes $(m a j \bar{a} m i)$ & $\begin{array}{l}\text { nos. } \underline{\mathbf{2 0 0}}, 201, \underline{\mathbf{2} 202}, \underline{\mathbf{2} 203}, \underline{\mathbf{2 0}} \mathbf{4}, 205,206,207,208, \\
\underline{\mathbf{2 0 9}}, 210,211, \underline{\mathbf{2 1 2}}, \underline{\mathbf{2 1 3}}, \underline{\mathbf{2 1}}, \underline{\mathbf{2 1}}, \mathbf{2 1 6}, 217,218,219\end{array}$ \\
\hline
\end{tabular}

in Șa da. The majority of titles represent the standard canon of Zaydi scholarship at the turn of the twentieth century, with a clear focus on Islamic law that is suggested by the proportionally high percentage of works on fiqh, legal theory and inheritance law. ${ }^{16}$

At the same time, the Imām al-Hādī library houses a number of rarities. For the Mu'tazilite tradition, these comprise an incomplete copy of the first part of the theological summa, K. al-Mu'tamad fì ușül al-dìn, by Rukn alDīn Mạ̣mūd b. al-Malāḥimī al-Khwārazmī (d. 536/1141), the principal

16 Cf. the madrasa al-ilmiyya that was opened in Bīr al-'Azab in Sanaa by Imām Yahyyā in 1344/1925-26 and its curriculum as described by Ismāīil al-Akwa', al-Madāris al-islàmiyya fī l-Yaman (Beirut/Sanaa: Mu'assasat al-risāla/Maktabat al-jīl al-jadīd, 1406/1986), 400-434. See also Brinkley Messick, The Calligraphic State: Textual Domination and History in a Muslim Society (Berkeley: University of California Press, 1996), 108-9; cf. also Kopp and Wirth, Beiträge zur Stadtgeographie von Sana'a, 38. 


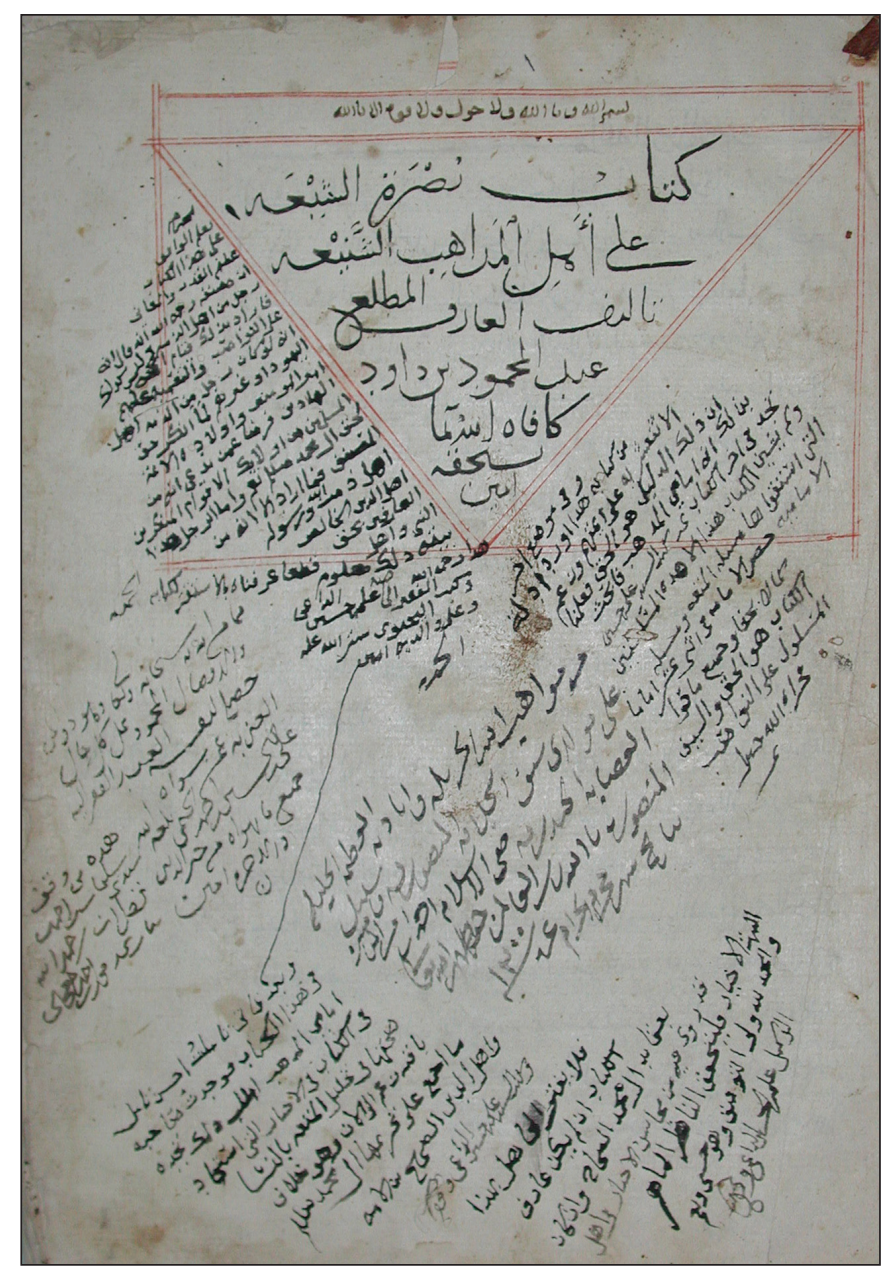

FIGU RE 2. Ms Ṣa da, Maktabat al-Imām Yahyā b. Husayn [ZMT 01674], title page.

representative of the school of Abū l-Husayn al-Bașrī (d. 436/1044); ${ }^{17}$ volume two of the latter's work on legal theory, K. al-Mu'tamad fì ușūl al-fiqh,

17 ZMT 01617; al-'Izzī, Fibris, 25 no. 7. The manuscript was consulted by Wilferd Madelung in the preparation of the revised edition of the work (Kitāb al-Mu'tamad fī ușūl al-dīn, revised and enlarged edition by Wilferd Madelung [Tehran: Mīrāth-i maktūb, 2012]). 


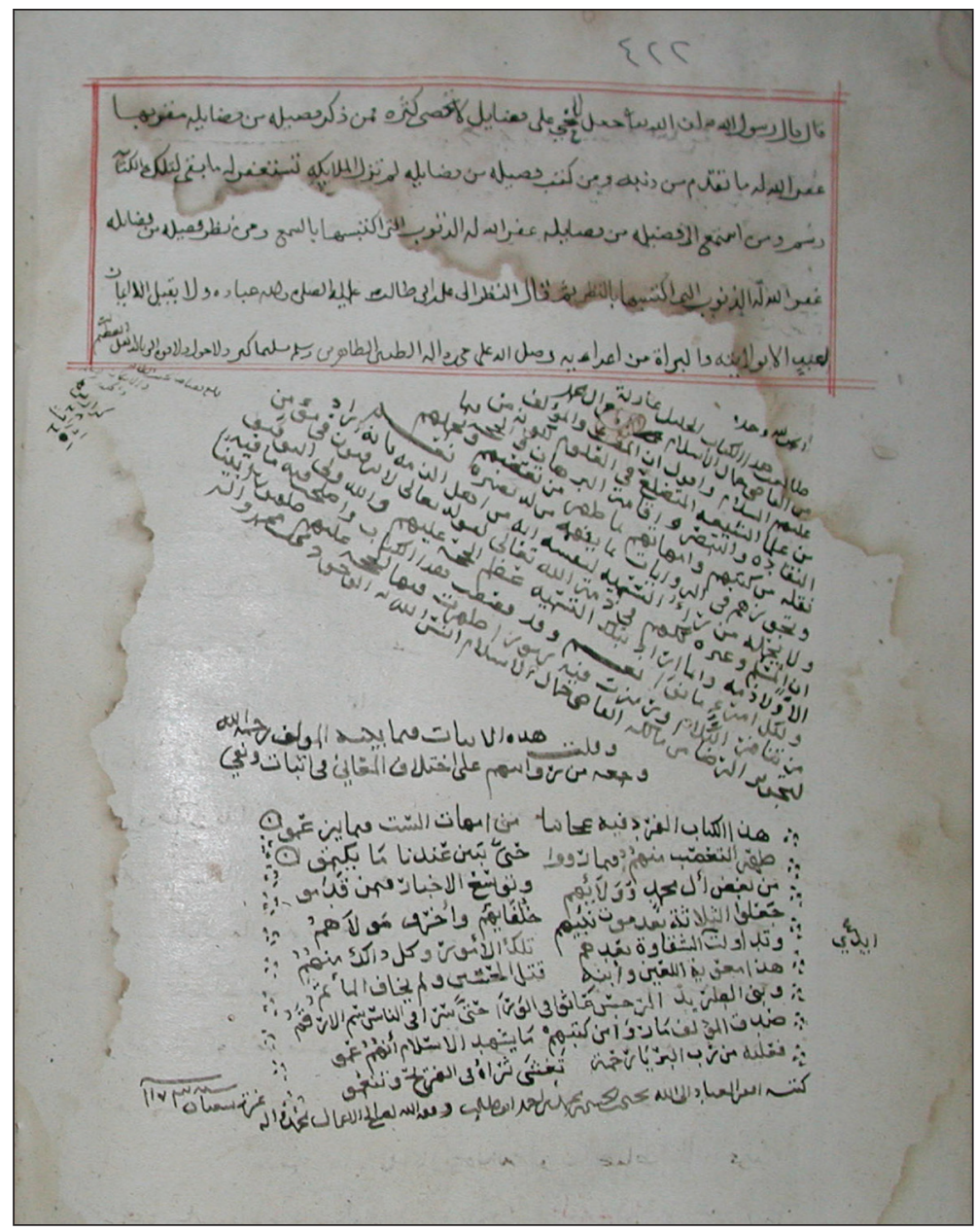

FIGURE 3. Ms Ṣa da, Maktabat al-Imām Yaḥyā b. Ḥusayn [ZMT 01674], p. 422.

which was popular among the Zaydis of Yemen; ${ }^{18}$ and an incomplete copy of the last volume of al-Ḥ̄àkim al-Jishumī's (d. 494/1101) Sharb 'Uyūn al-masā’il,

18 ZMT 01616; al-'Izzì, Fibris, 30 no. 15. This manuscript was not consulted by Muhammad Hamīd Allāh in his edition of the text (Damascus: al-Ma'had al-'ilmī al-faransī li-1-dirāsāt al-'arabiyya bi-Dimashq, 1964). See also Hassan Ansari and Sabine Schmidtke, Studies in Medieval Islamic Intellectual History, Resources in Arabic and Islamic Studies 7 (Atlanta: Lockwood Press, 2017), 73n36. 
an encyclopedic theological summa with detailed discussions of substances, physics, and biology from a Mu'tazilite theologian's point of view. ${ }^{19}$ This last part of the Sharb al-'Uyün is otherwise attested only in two manuscripts that are preserved in the Maktabat al-awqāf in Sanaa ${ }^{20}$ and in the library of the King Saud University. ${ }^{21}$ Another noteworthy work in the field of theology is 'Umdat al-mustarshidin, a theological summa by the prominent thirteenth-century Yemeni/Zaydī theologian Abū 'Abd Allāh Humayd b. Ahmad al-Muhallī (d. 652/1254). ${ }^{22}$ The library also has a copy of K. Nuṣrat al-shī'a 'alā abl al-madbābib al-shanī'a, by a certain "Abd al-Mahmmūd b. Dāwūd" (figs. 2 and 3). ${ }^{23}$ The author's name is a pseudonym of the renowned Imami scholar Raḍi al-Dīn 'Alī b. Mūsā Ibn Țāwūs (d. 664/1266), and the work in question is his polemical anti-Sunni text al-Tarä if f fi [ma'rifat] madhābb al-tawä'if. It is only among the Zaydis of Yemen that this otherwise famous work circulated under a different title that is attested in this manuscript. ${ }^{24}$ The manuscript of a theological work entitled Nibāyat dhawi al-'uqūl 'alā sharḅ̣ al-ușūl by a certain 'Alī b. Yahyā al-Husaynī seems to be a unicum. ${ }^{25}$ Of special value is further al-Masǟil al-nāfía bi-l-barābīn alqawiyya al-ṣādíca, by al-Ḥasan b. Yahyā b. 'Alī b. Aḥmad b. Qāsim al-Qāsimī al-Mu'ayyadī al-Ḍahyānī (1863/64-1924/25), which was transcribed from the

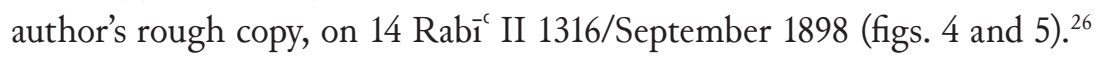

19 ZMT 01612. The manuscript is not described in al-'Izzîs catalog.

20 MS Sanaa, Maktabat al-awqāf no. 707. For a brief description of the manuscript, see Aḥmad 'Abd al-Razzāq al-Ruqayhī, 'Abd al-Allāh al-Hibshī, and 'Alī Wahhāb al-Ānsī, Fibrist makbtūṭāt maktabat al-Jāmi' al-kabìr Șan'ā' ([Sanaa:] Wizārat al-awqāf wa-1-irshād, 1404/1984), 2:663.

21 MS Riyadh, King Saud University Library no. 7783. For a description of the manuscript and a digital surrogate, see http://makhtota.ksu.edu.sa/makhtota/8453/1, accessed 3 October 2017. Together with Hassan Ansari, the present writer is currently preparing a critical edition of al-Hākim al-Jishumì's Sharḅ 'Uyūn al-masā̉il.

22 ZMT 01649; cf. al-'Izzī, Fibris, 22n1.

23 ZMT 01674. The codex is not described in al-'Izzìs catalog.

24 For the Tarā'if and Ibn Tāwūs's use of a pseudonym in this case, see Etan Kohlberg, $A$ Medieval Muslim Scholar at Work: Ibn Țāwūs and His Library, IPTS 12 (Leiden: Brill, 1992), 57-59 no. 51. For the reception of the work in Yemen and its peculiar title (which is not mentioned by Kohlberg), see Hassan Ansari, "Ṭarāif-i Ibn Ṭāwūs wa raddiya-āy barān," http://ansari.kateban.com/post/1234, accessed 5 October 2017.

25 ZMT 01675; cf. al-'Izzī, Fibris, 24 no. 5.

26 ZMT 01615. The manuscript is not described in al-'Izzî's catalog. For the author of the work, see al-Wajīh, A Tàm al-mu'allifīn al-Zaydiyya, 356-60 no. 351. 


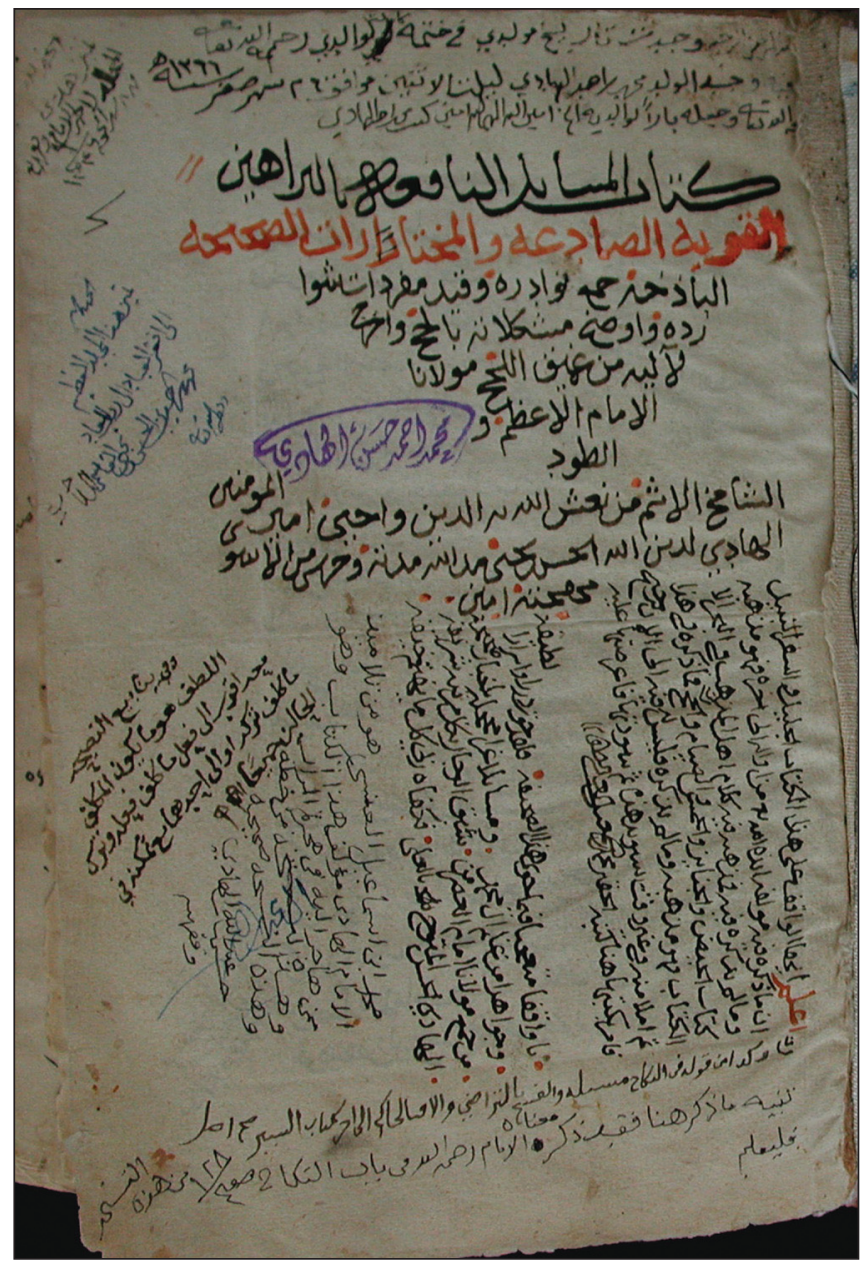

FIGU RE 4. Ms Ṣa da, Maktabat al-Imām Yahyā b. Husayn [ZMT 01615], title page.

The collection contains a fair amount of incomplete codices, with beginning and/or end missing. About two-third of the manuscripts are dated: nineteen manuscripts were produced during the eleventh/seventeenth century, eleven manuscripts were transcribed during the tenth/sixteenth century, eight manuscripts are dated to the ninth/fifteenth century, two manuscripts are dated to the eighth/fourteenth century, and two to the seventh/thirteenth 


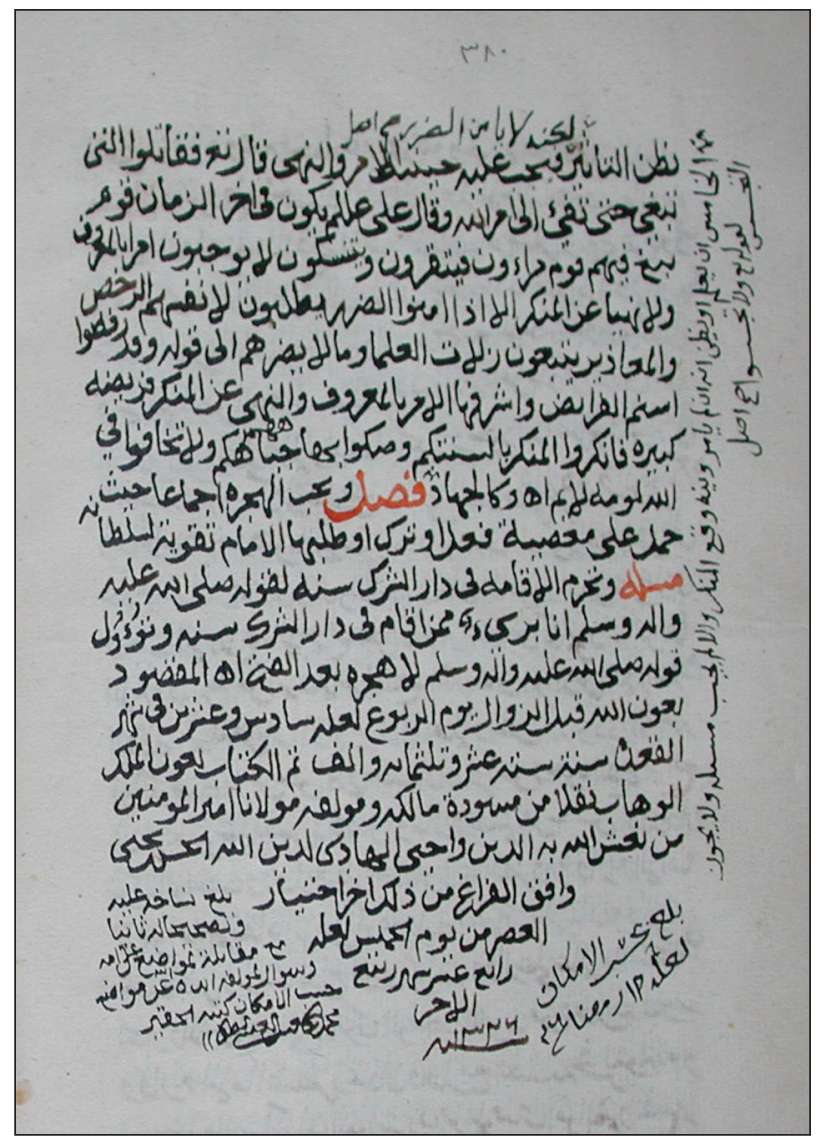

FIGURE 5. Ms Ṣa da, Maktabat al-Imām Yahyā b. Husayn [ZMT 01615], p. 380.

century, one manuscript to the twelfth/eighteenth century, and two to the thirteenth/nineteenth century. The oldest codex in the collection is a multitext volume containing the $K$. al-Maqāmāt of Abū Muhammad al-Qāsim b. 'Alī al-Harīīī al-Bașrī (d. 516/1122) (dated to Jumādā II 653) and the K. alNajm min kalām sayyid al-'arab wa-l-'ajam Muḅammad al-nabī al-mursal alkarìm by Ahmad b. Máadd b. 'İsā b. Wakīl al-Tujīīì al-Uqlīshī (d. 550/1155) 


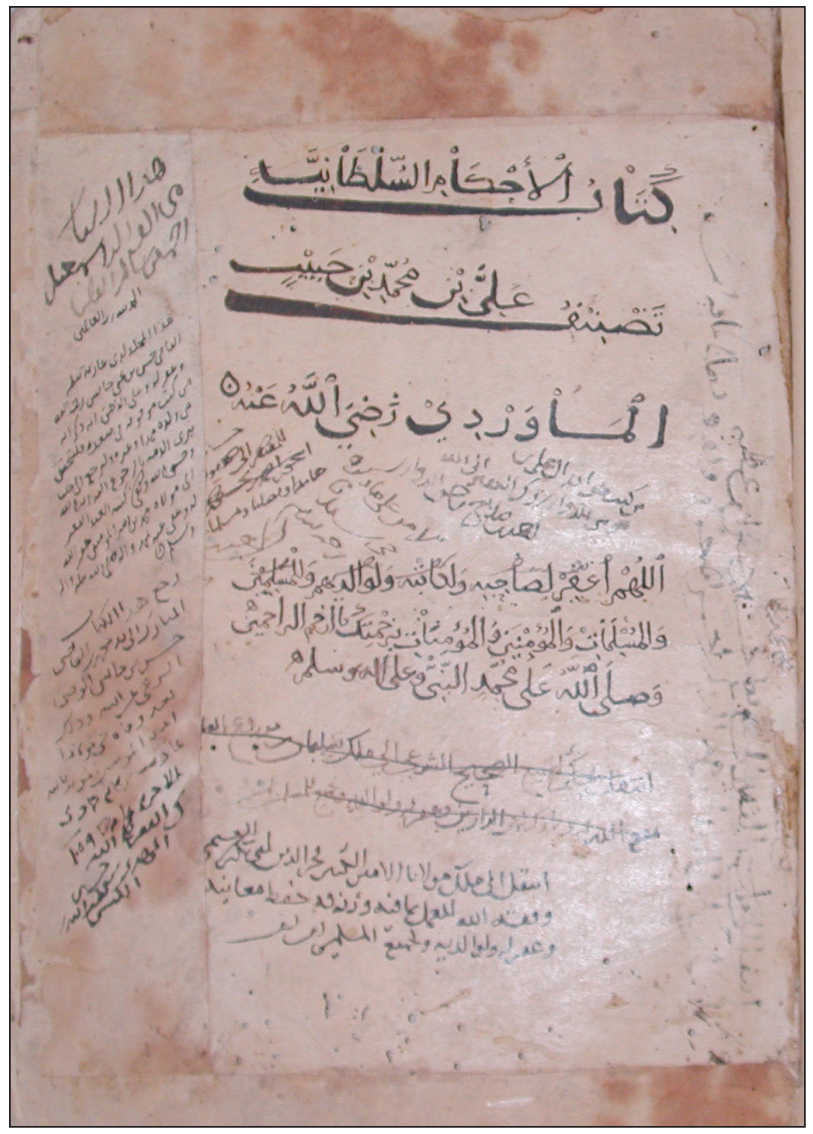

FIGURE 6. Ms Ṣa da, Maktabat al-Imām Yaḥyā b. Husayn, \#115 [ZMT 01603], title page.

(dated to Dhū 1-Qáda 553). ${ }^{27}$ It is followed by a precious copy of Abū l-Hasan al-Māwardìs (d. 450/1058) al-Ạ̣kām al-sulțāniyya that was completed in Rabî́c

27 ZMT 01669; cf. al-'Izzī, Fibris, 123-25; he renders both the title and the name of the author of the K. al-Najm as "K. al-Mu'jam min kalām . . ." by "Ahmad b. Mahdī b. 'Īsā." On the K. al-Najm and its author, see Carl Brockelmann, Geschicbte der arabischen Litteratur (GAL), Erweitert um ein Vorwort von Jan Just Witkam (Leiden: Brill, 2012), 1:456f. no. 6, vol. S 1:633 no. 6. For the reception of al-Harīin’s Maqāmāt among the Zaydis, see Ansari and Schmidtke, Studies in Medieval Islamic Intellectual History, 212 no. 87. Cf. also Shirley Guthrie, 


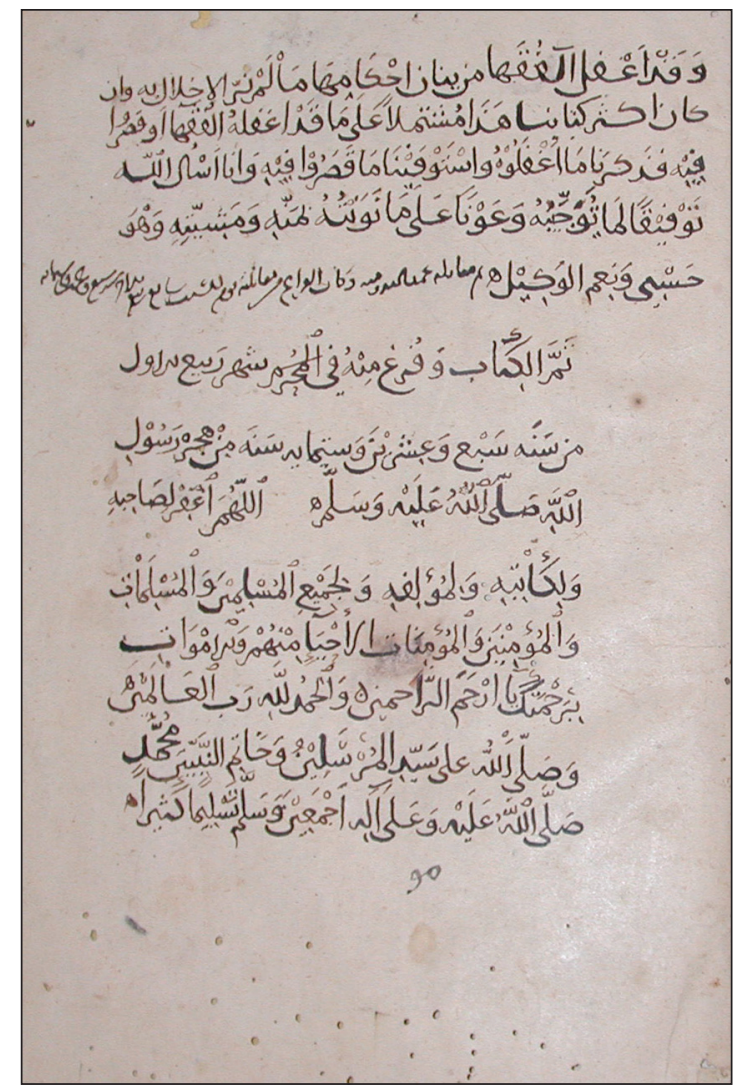

FIGURE 7. Ms Ṣa da, Maktabat al-Imām Yahyā b. Husayn, \#115 [ZMT 01603], final page.

I 627 (figs. 6 and 7) and has not been taken into consideration for any of the published versions of this important text. ${ }^{28}$ Another early codex contains volume one of the $K$. al-Luma'fífiqh Abl al-Bayt 'alaybim al-salām of al-Amīr 'Alī b. al-Husayn b. Yahyā b. Yahyā b. al-Nāṣir (fl. seventh/thirteenth century) (dated to Dhū 1-Qa'da 696), a legal work that was very popular among the

Al-Hariri's Maqamat: A Little-Known Illustrated Manuscript from Sana'a', Yemen, Dated 1709 (independently published, 2017).

28 ZMT 01603. See also al-'Izzī, Fibris, 46-47 no. 115. Al-'Izzī erroneously states that the manuscript is not dated. 
Zaydis of Yemen and is preserved in countless manuscripts. ${ }^{29}$ Eight manuscripts were transcribed, according to al-'Izzī, during the twentieth century. ${ }^{30}$ The overall ratio is again typical for the majority of Yemeni libraries.

29 Cf. al-'Izzī, Fibris, 39 no. 105. For the author and the work, see Ansari and Schmidtke, Studies in Medieval Islamic Intellectual History, 182 no. 9.

30 To the extent this could be verified, some of the dates provided by al-'Izzī in his catalog turned out to be erroneous. In more general terms, his descriptions are not always reliable and should be treated with some caution. 